\title{
Mucolipidosis II (I-Cell Disease): Sutudies of Muscle Biopsy and Muscle Cultures
}

\author{
SARA SHANSKE, ARMAND F. MIRANDA, AUDREY S. PENN, AND SALVATORE DIMAURO ${ }^{(29)}$ \\ H. Houston Merritt Clinical Research Center for Muscular Dystrophy and Related Diseases, Columbia University, \\ College of Physicians and Surgeons, New York, New York, USA
}

\begin{abstract}
Summary
Muscle cultures from a natient with I-cell disease showed the characteristic morphologic and biochemical abnormalities previously observed in cultured fibroblasts. At early stages of myoblast growth, there were numerous inclusions. Biochemically, the intracellular activities of $\beta$-galactosidase, $\beta$-hexosaminidase, and $\alpha$ mannosidase were reduced to 1,14 , and $5 \%$, respectively, of control values, and this was accompanied by elevated levels of $\beta$-hexosaminidase and $\alpha$-mannosidase in the culture medium. Cultures from the patient did not fuse as well as controls; however, when well-developed myotubes possessing distinct cross-striations were present, these no longer had inclusions. In the muscle biopsy from this patient, only $\beta$-galactosidase was decreased to approximately $50 \%$ of the mean control value whereas $\beta$-hexosaminidase and $\alpha$ mannosidase activities were increased as compared to controls. These data suggest that the I-cell mutation is expressed during early myogenesis but not in well-differentiated myotubes or mature muscle fibers.
\end{abstract}

\section{Speculation}

The expression of the I-cell mutation in cultured fibroblasts as compared to immature versus mature muscle suggests that the intracellular localization of acid hydrolases into lysosomes may occur via different pathways in different tissues and may also differ at various stages in development.

Mucolipidosis II or inclusion cell (I-cell) disease is an inherited lysosomal storage disorder clinically resembling a mucopolysaccharidosis, but without excessive excretion of mucopolysaccharides in urine. Clinical features include severe psychomotor retardation and growth failure, with death between the ages of 2 and 8 years $(11,22)$.

In cultured fibroblasts, there are typical cytoplasmic inclusions, hence the name I-cell disease (9). Unlike other lysosomal storage disorders in which a single lysosomal hydrolase is affected, biochemical studies of cultured I-cell fibroblasts have shown severe reduction or absence of several enzyme activities $(10,12,17,23$, 25 ). Also in contrast to other lysosomal enzyme deficiencies, in Icell disease the medium from cultured fibroblasts and extracellular fluids (plasma, urine and cerebrospinal fluid) have increased activities of several lysosomal hydrolases $(2,24,25)$.

The primary defect in I-cell disease is not known, but recent studies suggest that the abnormality does not involve synthesis of the lysosomal hydrolases but their cellular localization. It was shown that lysosomal enzymes secreted from normal fibroblasts are specifically recognized and taken up by other fibroblasts through a recognition marker on the enzymes containing mannose-phosphate $(6,7,16,20)$. The lysosomal hydrolases secreted from cultured I-cell fibroblasts are not recognized and pinocytosed, suggesting a posttranslational modification affecting the recognition marker $(5,18)$.
In contrast to the defect of multiple hydrolases found in fibroblasts, examination of postmortem specimens of liver, brain, spleen, and kidney from I-cell patients showed an isolated decrease of acid $\beta$-D-galactosidase $(10,14,22)$. The activities of several other lysosomal hydrolases were unaffected or even slightly increased. The purpose of the present study was to examine the effects of the I-cell mutation on muscle. We studied muscle morphology as well as several lysosomal enzymes in the muscle biopsy from a patient with I-cell disease. We also performed morphologic and biochemical investigations of muscle cultures from this patient to see if the defect observed in cultured fibroblasts was also expressed in cultured muscle and if the expression of the disease changed during myogenesis in vitro.

\section{MATERIALS AND METHODS}

\section{SOURCE OF TISSUES}

Control skeletal muscle biopsies were obtained for diagnostic purposes with informed consent from patients who were ultimately deemed to be free of muscle disease. The patient (a 3-year-old girl) had been studied (with informed parental consent) at Downstate Medical Center (Brooklyn, NY) and Mount Sinai Hospital (New York). The diagnosis of I-cell disease was based on the clinical picture and elevated $\beta$-hexosaminidase activity in plasma and confirmed by studies of cultured fibroblasts. A detailed description of the clinical findings will be reported elsewhere (8). All specimens were frozen immediately and stored in liquid nitrogen.

\section{MUSCLE CULTURE}

Muscle explants were planted in $35 \mathrm{~mm}$ Costar cluster dishes and grown as previously described (15). After removal of the explants, the outgrowths were trypsinized and plated selectively. Inasmuch as fibroblasts attach more rapidly to appropriate substrates than myoblasts, it is possible to reduce fibroblast contamination considerably by allowing the trypsinized primary cells to settle and adhere for 15 to $20 \mathrm{~min}$. The myoblast-rich supernate is then decanted into an appropriate culture vessel for further growth and differentiation. The selective plating method was used for rat myoblasts by Yaffe (26) in which $40 \mathrm{~min}$ of selective attachment were needed. For human myoblasts, 15 to $20 \mathrm{~min}$ of selective plating appears optimal (15). For experiments in which extracellular enzyme activities were determined in culture medium, cells were grown in Eagle's minimal essential medium supplemented with $5 \%$ heat-inactivated fetal calf serum $\left(70^{\circ} \mathrm{C}\right.$ for $30 \mathrm{~min})$.

\section{CLONING}

Trypsinized cells were plated at 200 to 400 cells per $100 \mathrm{~mm}$ dish in complete medium and left undisturbed for 21 days. Some duplicate clonal cultures were reincubated 14 days longer, after refeeding, to determine whether fusion would proceed in the 
patients' cultures. In both control and patient's cultures, 9 to $18 /$ 100 cells per dish developed into colonies. The percentage of fusing colonies was determined in an inverted Zeiss microscope and representative clones were photographed with phase optics.

\section{HISTOCHEMISTRY}

Control and patient's monolayer cultures were grown on $22 \mathrm{~mm}$ coverslips in $35 \mathrm{~mm}$ cluster dishes. After $2 \mathrm{wk}$ in culture, the cells were fixed with $10 \%$ neutral formalin (from paraformaldehyde) for $10 \mathrm{~min}$, rinsed, rapidly air-dried, stained for acid phosphatase (1) for $1 \mathrm{hr}$, and examined by conventional light microscopy.

\section{IMMUNOCYTOCHEMISTRY}

To identify differentiating muscle elements, cultures grown on cover slips were fixed with acetone or $100 \%$ ethanol for $15 \mathrm{sec}$, and air-dried. They were then exposed to human serum from a patient with myasthenia gravis and a thymoma which was known to contain autoantibodies specific for human myofibrillar A-band antigens by indirect immunofluorescence analysis (19). This serum was applied at dilutions of 1:40 and 1:100, allowed to react for 30 min, rinsed five times with phosphate-buffered saline (PBS; $\mathrm{pH}$ 7.4) and stained with fluorescein-tagged rabbit anti-human IgG (Hyland Division, Travenol) at dilutions of $1: 10$ or 1:100. The coverslips were rinsed 5 times $(15 \mathrm{~min})$ with $\mathrm{PBS}$, mounted in PBS-buffered glycerin, examined using a Zeiss microscope with fluorescence optics, and photographed using Tri X Kodak film. Skin fibroblasts grown similarly did not show any fluorescence when stained with this antibody.

\section{CREATINE KINASE (CPK) ISOENZYMES}

Muscle culture homogenates were applied to cellulose acetate membranes (Helena Laboratories, Beaumont, TX), exposed to substrate, with adenosine dipentaphosphate added to inhibit protein kinase activity, and analyzed as previously described (15). Visualization of the CPK bands is based on the conversion of NADP to NADPH (fluorescent), with a CPK standard (Helena Laboratories) used to localize migrating bands.

\section{TISSUE PREPARATION}

For enzyme assays, muscle biopsy specimens were homogenized in 9 volumes of distilled water in all-glass homogenizers at $4^{\circ} \mathrm{C}$. Homogenates were centrifuged at $750 \times g$ for $10 \mathrm{~min}$ and the supernatants were used in the assays. Cultured muscle cells were detached with $0.125 \%$ trypsin (Grand Island Biological Co.) in Earle's balanced salt solution containing 0.15\% Versene (Dow Chemical Co.), rinsed three times with cold PBS, and frozen at $-70^{\circ} \mathrm{C}$. For enzyme assays, pellets were resuspended in appropriate volumes of distilled water, sonicated with an Artek Sonic 300 for $2 \times 30 \mathrm{sec}$, and centrifuged at $750 \times \mathrm{g}$ for $10 \mathrm{~min}$, and the supernatants were used in the assays.

\section{ENZYMATIC ASSAYS}

Acid and neutral $\alpha$-glucosidases, $\beta$-galactosidase, $\alpha$-mannosidase, and $n$-acetyl- $\beta$-D-glucosaminidase $(\beta$-hexosaminidase) were assayed with the corresponding 4-methylumbelliferyl (MU) substrates. For $\beta$-galactosidase, $\alpha$-mannosidase, and $\beta$-hexosaminidase, the reaction mixture contained, in a final volume of $0.4 \mathrm{ml}$, $0.1 \mathrm{M}$ sodium acetate buffer $\mathrm{pH} 4.5,50 \mu \mathrm{l}$ sample, and $0.9 \mathrm{mM} 4$ MU- $\beta$-D-galactoside, $1.4 \mathrm{mM} 4-\mathrm{MU}-\alpha$-mannopyranoside, or 2.5 $\mathrm{mM} 4$-MU- $N$-acetyl- $\beta$-D-glucosaminide, respectively. For the acid and neutral $\alpha$-glucosidases, the reaction mixture contained, in a final volume of $0.4 \mathrm{ml}, 0.2 \mathrm{M}$ potassium acetate buffer, $\mathrm{pH} 4.0$, or $0.2 \mathrm{M}$ potassium citrate buffer, $\mathrm{pH} 6.5,50 \mu \mathrm{l}$ sample, and $1.4 \mathrm{mM}$ 4-MU- $\alpha$-D-glucoside. For all enzymes, incubation was for $1 \mathrm{hr}$ at $37^{\circ} \mathrm{C}$. The reaction was stopped by adding $1.6 \mathrm{ml} 1 \mathrm{M}$ glycinesodium carbonate buffer, $\mathrm{pH}$ 10.0, and fluorescence of the liberated methylumbelliferone was measured in an Amicon-Bowman fluorometer. Protein was determined by the method of Lowry et al. (13) with bovine albumin as standard.

\section{RESULTS}

Muscle cultures from the patient and four controls had a population doubling time of approximately $45 \mathrm{hr}$. However, the control cells showed extensive fusion after 12 days (fusion index, 75 to $80 \%$ ), whereas the patient's muscle culture failed to fuse normally. In the latter, the fusion index after 12 days was only $10 \%$ and did not increase significantly even after 2 more weeks of cultivation. Both mononuclear cells and developing myotubes from the patient were refractile because of numerous inclusion bodies. These inclusions were similar to those described in I-cell fibroblasts (9) and can be assumed to be lysosomes because, unlike controls, the patient's cells stained very intensely for acid phosphatase histochemically.

To determine whether the low fusion index in the patient's culture was due to the inhibition of fusion, rather than fibroblast contamination, colonies derived from single cells were studied. Such colonies (clones) were obtained when cells were grown at densities of 200 to 400 per $100 \mathrm{~mm}$ dish. In control cultures, about $60 \%$ of the clones showed extensive fusion after 21 days (Fig. $1 a$ ), whereas clonal cultures derived from the patient's muscle did not show much fusion. Approximately $40 \%$ of these clones could be identified with certainty as muscle because of the presence of myotubes, but most of the myotubes were generally smaller than controls and contained no more than three nuclei; the remaining cells were usually elongated or spindle-shaped and aligned in parallel (Fig. $1 b$ ). Large myotubes remained absent even in 35day-old clonal cultures.

When the clones were examined $72 \mathrm{hr}$ after cross-feeding with medium previously exposed to normal fusing muscle cultures for $24 \mathrm{hr}$ and filtered through a $0.22 \mu$ Millipore filter, there was no enhancement of fusion in the patient's culture up to $96 \mathrm{hr}$. Similarly, medium exposed to the patient's culture did not affect the fusion of control cultures.

\section{IMMUNOCYTOCHEMISTRY}

To determine whether the patient's myoblasts which failed to fuse were differentiating or not, monolayer cultures from patient and controls were exposed to human serum containing antibodies previously shown to be specific for human myofibrillar A-band antigens (see "Materials and Methods"). The serum-treated cells were then exposed to fluorescein-tagged anti-human IgG. In control cultures, the multinucleate myotubes were brilliantly stained and most mononuclear cells were not. However, in the patient's culture, most cells that were fluorescent were mononuclear with some bi- and trinucleate myotubes (Fig. $2 a$ and $b$ ). In both control and patient's cultures, there were some normalappearing, well-developed myotubes with distinct cross-striations (Fig. 2c).

\section{CPK ISOENZYMES}

CPK isoenzyme patterns can be used as a criterion for muscle differentiation (15). This enzyme has a dimeric structure with two subunits, $M$ and $B$. Mature skeletal muscle has almost exclusively the MM isoenzyme and the differentiation of muscle in culture is accompanied by a rise of muscle-specific CPK (MM). The electrophoretic pattern of CPK isoenzymes, ie., intensity of the MM and MB hybrid bands, were similar in control and patient's cultures (Fig. 3), suggesting that all cultures studied were at a similar stage of differentiation and that there was little fibroblast contamination because cultured skin fibroblasts have only the BB isoenzyme (data not shown).

INTRACELLULAR ACTIVITIES OF LYSOSOMAL ENZYMES IN MUSCLE CULTURES

Muscle cultures from the patient and controls were harvested and assayed for $\beta$-galactosidase, $\alpha$-mannosidase, and $\beta$-hexos- 

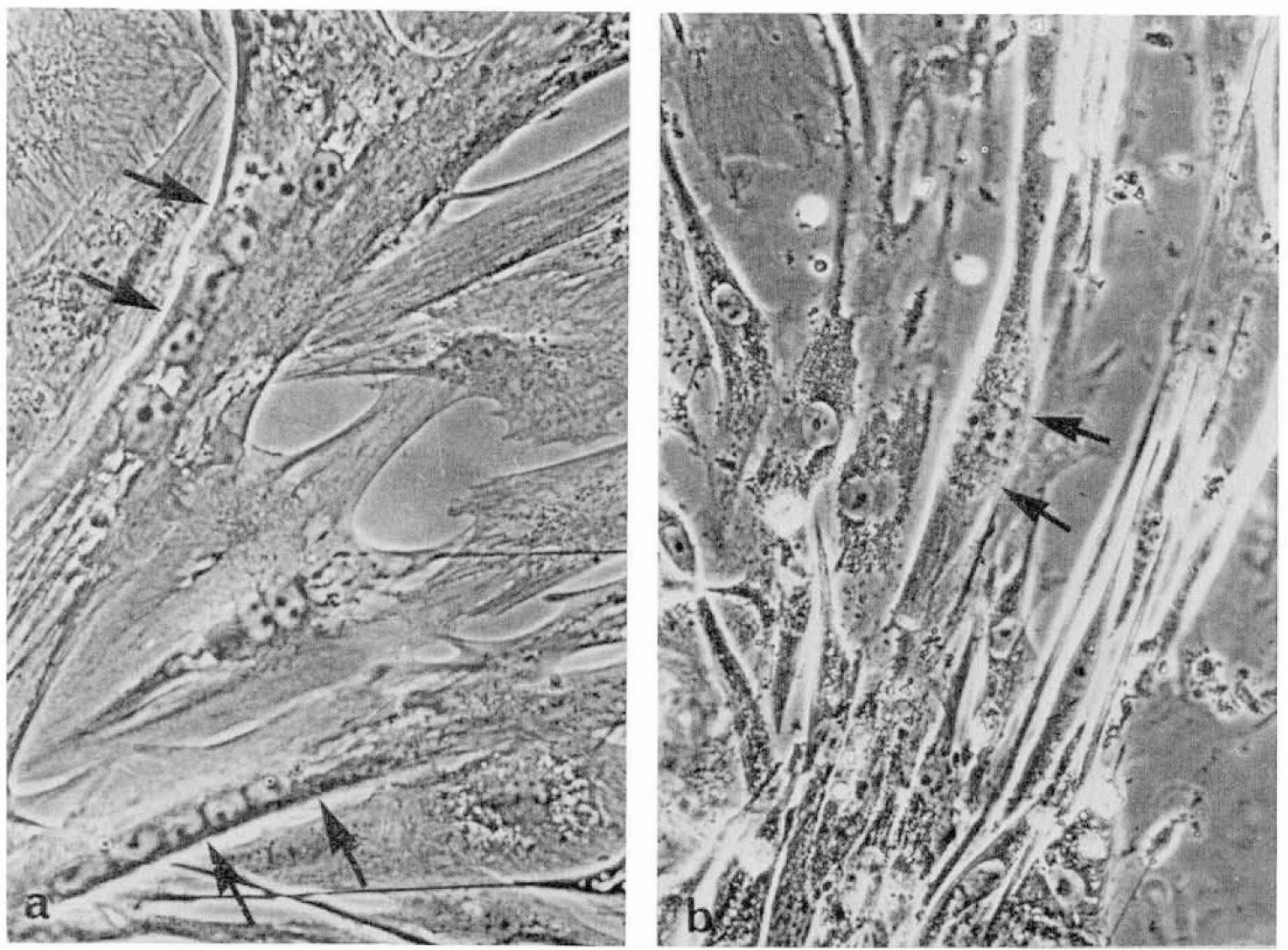

Fig. 1. $a$, control culture: central area of a muscle cell clone grown for 21 days. Most myoblasts have fused to form elongated or multipolar multinucleated syncytia (arrows); $b$, patient culture: central area of a muscle cell clone derived from the patient's muscle. After 21 days, only few bi- or trinucleate syncytia (arrows) are discernable. Most other cells are mononculear, spindle shaped, and aligned in parallel. Both myoblasts and developing myotubes are refractile because of numerous inclusion bodies. Phase microscopy, $\times 650$.
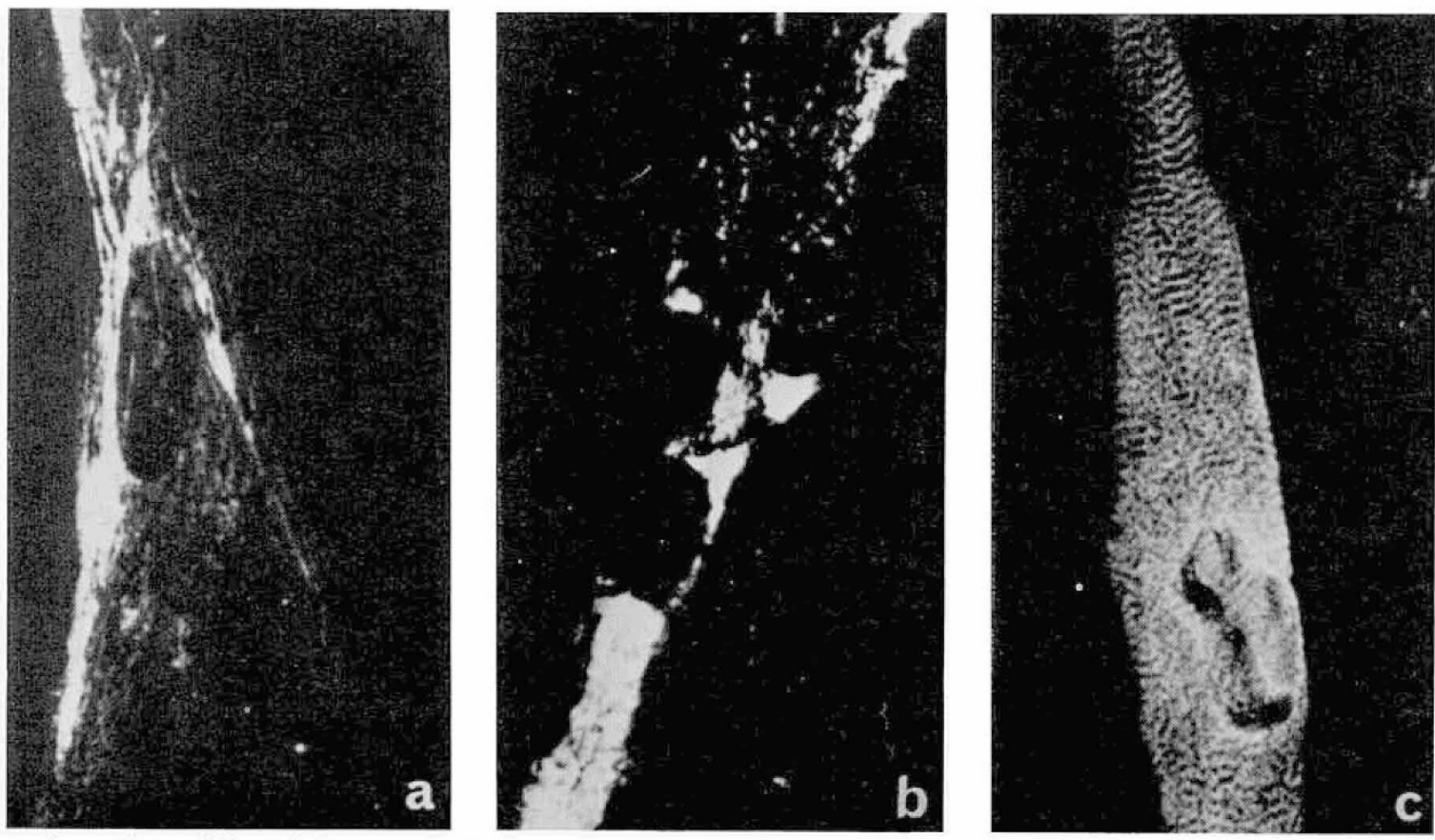

Fig. 2. $a$, patient culture, differentiating mononuclear muscie cell in a monolayer culture 14 days after selective plating. Myofibrillar elements are fluorescent after indirect staining with fluorescein-tagged antibody, as described in "Materials and Methods"; $b$, trinucleate myotube in the same culture shown in $a$, with patchy myofibrillar staining. The uneven distribution of fluorescein label appears to be due to numerous lysosome-like inclusion bodies; $c$, well-differentiated myotube with numerous cross-striations. In differentiating cultures, a few myotubes are well-differentiated, with numerous cross-striations. These well-developed myotubes have very few inclusions and are indistinguishable from controls $(\times 800)$. 


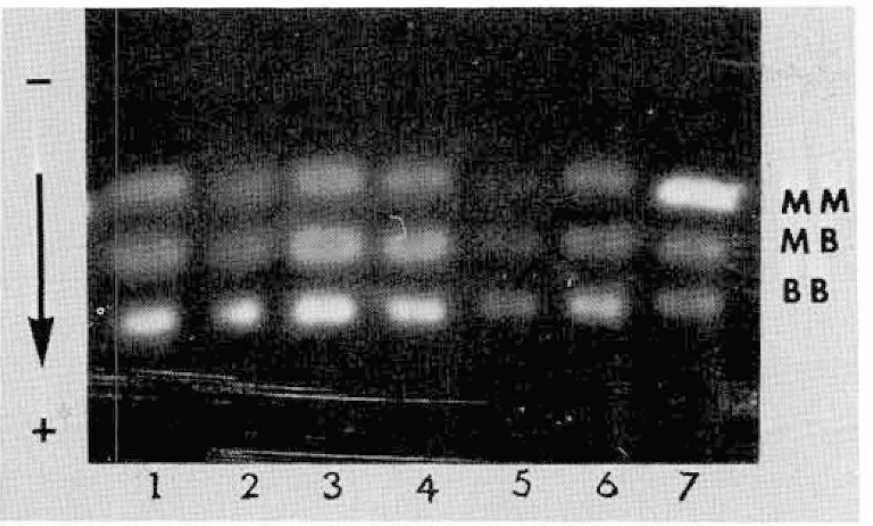

Fig. 3. CPK isoenzyme patterns. Lanes 1 and 6, patient; lanes 2 to 5 , controls; lane 7, CPK standard.

Table 1. Enzyme activities in control and I-cell muscle cultures ${ }^{1}$

\begin{tabular}{lccccc}
\hline & $\begin{array}{c}\text { Acid } \alpha- \\
\text { glucosi- } \\
\text { dase }\end{array}$ & $\begin{array}{c}\text { Neutral } \alpha- \\
\text { glucosi- } \\
\text { dase }\end{array}$ & $\begin{array}{c}\beta \text {-Galac- } \\
\text { tosidase }\end{array}$ & $\begin{array}{c}\beta \text {-Hexosa- } \\
\text { minidase }\end{array}$ & $\begin{array}{c}\alpha \text {-Man- } \\
\text { nosidase }\end{array}$ \\
\hline Controls & & & & & \\
1 & 49.6 & N.D. & 646.6 & 644.3 & N.D. \\
2 & 79.9 & 179.5 & 1181.4 & 1164.9 & 482.1 \\
3 & 95.8 & 115.4 & 1177.8 & 617.6 & 313.4 \\
4 & 100.8 & 96.6 & 731.8 & 484.6 & 311.6 \\
Mean & 81.5 & 130.2 & 934.4 & 727.9 & 369.0 \\
& & & & & \\
"I-cell" & 48.1 & 115.8 & 11.8 & 98.0 & 19.1 \\
\% control & $59 \%$ & $89 \%$ & $1 \%$ & $14 \%$ & $5 \%$ \\
\hline
\end{tabular}

${ }^{1}$ Specific activities, nmoles MU per $60 \mathrm{~min}$ per $\mathrm{mg}$ protein.

aminidase, three lysosomal hydrolases known to have decreased activity in fibroblasts cultured from patients with I-cell disease $(10,12)$. We also studied the activity of acid $\alpha$-glucosidase, a lysosomal enzyme not reported to be affected in I-cell fibroblasts, as well as neutral $\alpha$-glucosidase, a nonlysosomal enzyme that may be related to acid $\alpha$-glucosidase but whose function is not known.

The three enzymes which are decreased in I-cell fibroblasts were also markedly decreased in I-cell muscle cultures. The specific activities of $\beta$-galactosidase, $\beta$-hexosaminidase, and $\alpha$-mannosidase in the I-cell muscle cultures were 1,14 , and $5 \%$, respectively, of the mean values of 4 controls (Table 1). Acid $\alpha$-glucosidase activity was less than the mean control value, but comparable to that of one control culture. Neutral $\alpha$-glucosidase activity was not affected.

\section{EXTRACELLULAR ACTIVITIES OF LYSOSOMAL ENZYMES IN MUSCLE CULTURES}

Inasmuch as cultured fibroblasts from I-cell patients show excessive secretion of lysosomal enzymes into the growth medium $(24,25)$, we studied the activities of $\beta$-galactosidase, $\alpha$-mannosidase, and $\beta$-hexosaminidase in the medium of I-cell and control muscle cultures. Figure 4 shows the data obtained for $\beta$-hexosaminidase. Control cultures secreted some hexosaminidase into the medium, but the extracellular activity after $48 \mathrm{hr}$ was always less than $50 \%$ of the intracellular activity. In contrast, in I-cell cultures $\beta$-hexosaminidase activity in the medium was more than seven times greater than inside the cells after $48 \mathrm{hr}$. Even at $4 \mathrm{hr}$, the earliest time point tested, these cultures had more activity extracellularly than intracellularly. Total enzyme activities (extracellular plus intracellular) for $\beta$-hexosaminidase and $\alpha$-mannosidase were comparable in I-cell and control cultures, but they were predominantly intracellular in control cells whereas in I-cell cultures approximately $90 \%$ of total activity was in the medium (Fig. $5)$. The intracellular activity of the third lysosomal hydrolase

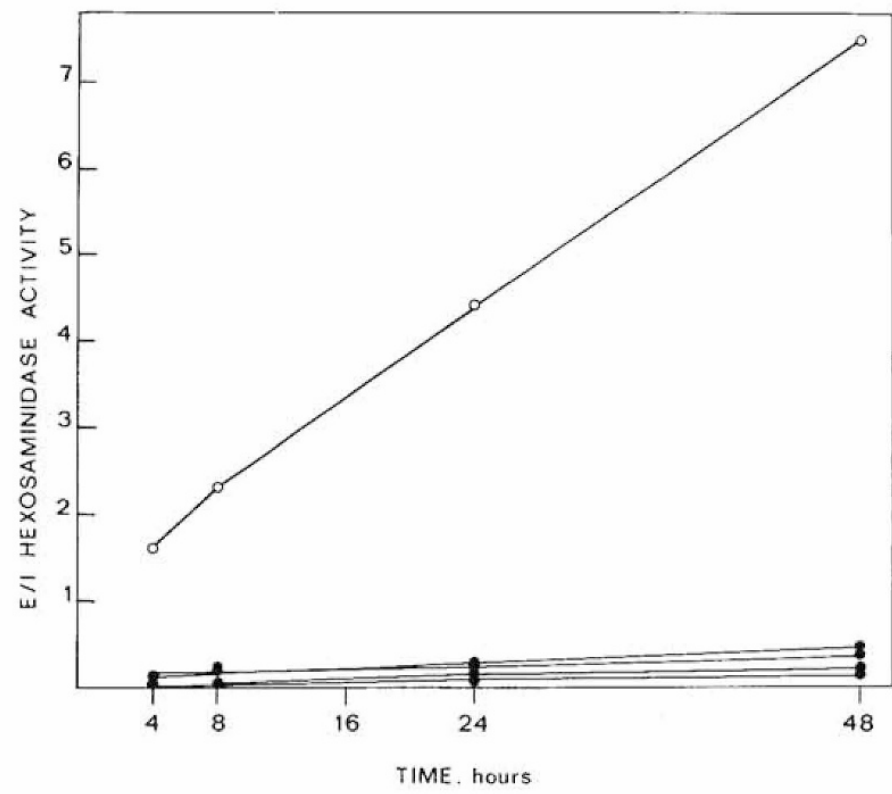

Fig. 4. Extracellular/Intracellular $(E / I) \quad \beta$-Hexosaminidase activity. - controls $(n=4)$; $\bigcirc$, I-cell; activity, 1 unit will release 1 nmole of $\mathrm{MU}$ / $60 \min$ at $37^{\circ} \mathrm{C}$.

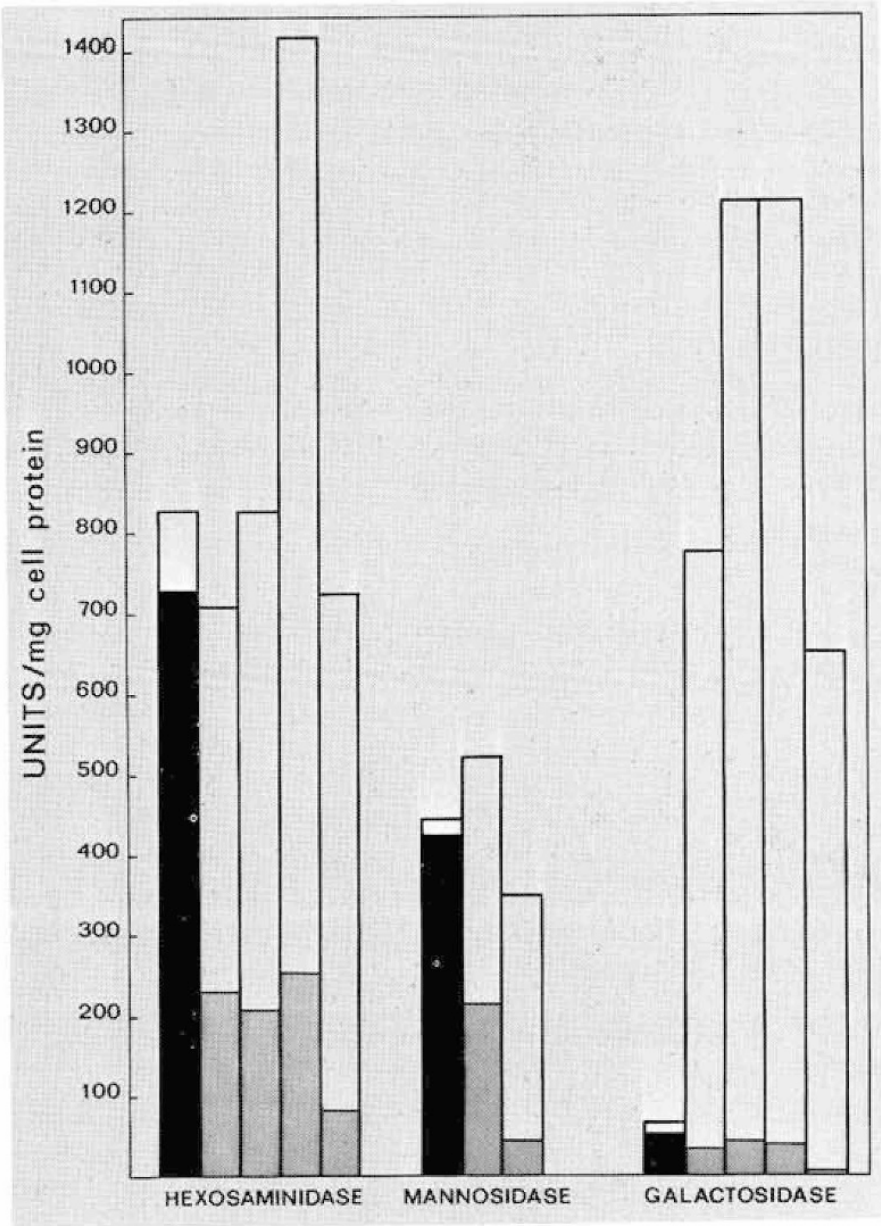

Fig. 5. Intracellular versus extracellular activity of three lysosomal enzymes in control and I-cell muscle cultures. $\square$, intracellular activity; 중, extracellular activity: controls; $\mathbf{m}$, extracellular activity: 1-cell. $\mathrm{Bar}=$ control culture; 1 unit, amount of enzyme that will release 1 nmole of MU per 60 $\min$ at $37^{\circ} \mathrm{C}$ 
Table 2. Enzyme activities in control and I-cell muscle

\begin{tabular}{|c|c|c|c|c|c|}
\hline & $\begin{array}{c}\beta \text {-Galac- } \\
\text { tosidase }\end{array}$ & $\begin{array}{c}\beta \text {-Hexosa- } \\
\text { minidase }\end{array}$ & $\begin{array}{c}\alpha \text {-Manno- } \\
\text { sidase }\end{array}$ & $\begin{array}{l}\text { Acid } \alpha- \\
\text { glucosi- } \\
\text { dase }\end{array}$ & $\begin{array}{c}\text { Neutral } \alpha- \\
\text { glucosi- } \\
\text { dase }\end{array}$ \\
\hline \multicolumn{6}{|l|}{ Controls } \\
\hline 1052 & 6.2 & 11.9 & 4.9 & 6.5 & 10.1 \\
\hline 1201 & 16.8 & 17.7 & 4.0 & 4.4 & 25.1 \\
\hline 1209 & 4.5 & 8.3 & 2.2 & 5.5 & 4.9 \\
\hline 1014 & 9.5 & 10.3 & 5.1 & 6.7 & 13.2 \\
\hline 1244 & 6.8 & 9.9 & 3.0 & 6.4 & 9.7 \\
\hline 1245 & 11.8 & 17.0 & 3.7 & 6.2 & 13.5 \\
\hline 1090 & 8.8 & 20.2 & 4.0 & 11.3 & 21.2 \\
\hline Mean & 9.2 & 13.6 & 3.8 & 6.7 & 14.0 \\
\hline \multirow[t]{2}{*}{ "I-cell" } & 4.2 & 55.3 & 31.3 & 11.9 & 15.9 \\
\hline & 4.0 & 43.5 & 25.3 & 12.1 & 18.4 \\
\hline Mean & 4.1 & 49.4 & 28.3 & 12.0 & 17.2 \\
\hline $\begin{array}{l}\text { I-cell/con- } \\
\text { trol }\end{array}$ & 0.5 & 3.6 & 7.5 & 1.8 & 1.2 \\
\hline
\end{tabular}

${ }^{1}$ Specific activities, nmoles MU per 60 min per mg noncollagen protein.

examined, $\beta$-galactosidase, was also markedly decreased in I-cell cultures but there was no concomitant increase in extracellular activity. Inasmuch as the extracellular activity was measured in aliquots of medium after $48 \mathrm{hr}$ in culture, $\beta$-galactosidase activity may have been inactivated under these conditions. To test this possibility, an extract of control muscle culture, having $\beta$-galactosidase, $\alpha$-mannosidase, and $\beta$-hexosaminidase activities, was exposed to cell culture conditions by incubating it at $37^{\circ} \mathrm{C}$ with Eagle's minimal essential medium containing $5 \%$ heat inactivated newborn calf serum. Repeated assays of this enzyme-containing medium showed that, although $\beta$-hexosaminidase and $\alpha$-mannosidase activities were stable, the $\beta$-galactosidase activity was completely lost after $4 \mathrm{hr}$. These findings suggest that the severe intracellular deficiency of $\beta$-galactosidase in the I-cell cultures is also accompanied by loss of the enzyme into the growth medium, but this extracellular activity cannot be detected because the enzyme is not stable in the medium.

\section{LYSOSOMAL HYDROLASE ACTIVITY IN MUSCLE BIOPSY}

The activities of $\beta$-galactosidase, $\beta$-hexosaminidase, and $\alpha$-mannosidase, as well as acid and neutral $\alpha$-glucosidase in the muscle biopsy from the I-cell patient were compared to a series of seven controls, four children and three adults. Table 2 shows that in the I-cell muscle, both $\beta$-hexosaminidase and $\alpha$-mannosidase activities were significantly greater than normal. Only $\beta$-galactosidase activity was decreased to approximately $50 \%$ of the mean control value. Neither acid nor neutral $\alpha$-glucosidase activities appeared to be significantly different from controls.

\section{DISCUSSION}

I-cell disease was defined on the basis of fibroblast cultures, which have typical cytoplasmic inclusions and a severe reduction of several lysosomal enzyme activities. In contrast, several tissues studied at autopsy (liver, brain, kidney, and spleen) had normal or increased activity for the same lysosomal enzymes with only $\beta$-galactosidase activity reduced by 10 to $50 \%(10,14,22)$. Our study indicates that muscle is no exception; a muscle biopsy from this patient did not show the decrease in activity of lysosomal enzymes seen in fibroblasts. Only $\beta$-galactosidase was decreased to approximately $50 \%$ of the mean control value, but $\beta$-hexosaminidase and $\alpha$-mannosidase activities were higher than normal. It is possible that enzyme levels measured in homogenates of a muscle biopsy may reflect contamination of the muscle fibers with blood, which has elevated levels of lysosomal enzymes in patients. However, a primary deficiency of these enzymes in muscle fibers is unlikely because muscle fibers appeared normal morphologically, and only satellite cells showed inclusions similar to those seen in fibroblasts (8).

In contrast to these observations in mature muscle fibers, the Icell mutation is expressed in muscle cultures both morphologically and biochemically. At early stages of myoblast growth, the patient's cultures showed numerous inclusions and were indistinguishable from I-cell fibroblasts. Biochemically, the intracellular activities of $\beta$-galactosidase, $\beta$-hexosaminidase, and $\alpha$-mannosidase were markedly reduced, and this was accompanied by elevated levels of the same enzymes in the growth medium. Inclusions were also present in newly formed myotubes. However, at later stages, well-developed myotubes possessing distinct cross-striations no longer had inclusions. These findings, combined with the observation in the muscle biopsy of inclusions in the precursor satellite cells, indicate that the I-cell mutation may have an effect at early stages of muscle development but not in well-differentiated myotubes or mature muscle fibers.

It was also observed that the patient's cultures did not fuse as well as controls. This may be due to a membrane alteration, and a membrane defect in I-cell disease has indeed been suggested based on studies of fibroblasts $(3,21)$. However, postulating a membrane defect which does not allow effective myoblast fusion makes it difficult to explain why muscle eventually develops and matures normally in vivo in I-cell patients. Possibly, although fusion may be less efficient than normal initially, there might be some selection during myogenesis in these patients, and those myoblasts that do fuse would go on to form normal muscle fibers. We considered the possibility that the poor fusion of myoblasts in vitro may be due to the presence of high levels of lysosomal enzymes in the growth medium. However, this is unlikely because medium from I-cell cultures did not interfere with fusion in control cultures. Thus, the contrast between normal muscle development in vivo and inefficient myoblast fusion in vitro remains unexplained.

The primary defect in I-cell disease is not known, but evidence suggests that there is an alteration of some post-translational processing common to the hydrolases that is required to package them into lysosomes. Fibroblasts take up lysosomal enzymes from the culture medium, and this uptake shows the selectivity and saturability expected for a receptor-mediated process $(6,20)$. Studies with I-cell fibroblasts showed that these cells could pinocytose and retain normal lysosomal enzymes. However, enzymes secreted by I-cell fibroblasts could not be taken up by either normal or I-cell fibroblasts (5). It was therefore proposed that Icell disease hydrolases lacked a specific recognition marker. $\mathrm{Re}-$ cent evidence has confirmed these initial observations and suggested that mannose-6- $\mathrm{PO}_{4}$ is an essential component of the recognition marker required for incorporation of enzymes into lysosomes $(7,16)$. Hasilik and Neufeld (4) showed that lysosomal enzymes produced by normal fibroblasts are phosphorylated on mannose residues, whereas enzymes produced by I-cell fibroblasts are not phosphorylated. Whether a defect of the phosphorylating system is the primary error in I-cell disease or is only a secondary manifestation remains to be elucidated.

Whatever the primary defect, it seems clear that the low intracellular activity of several lysosomal enzymes and their abnormally high activity in culture medium and body fluids is due to a defective recognition marker on these hydrolases which does not allow for their proper intracellular localization, i.e., packaging into lysosomes. Our findings suggest that this system for packaging lysosomal enzymes is operative and important in cultured myoblasts and probably in the early stages of myogenesis in vivo, but there may be some different mechanism operative in mature muscle. We do not know whether the lysosomal enzyme activity measured in mature muscle is due to adequately processed intralysosomal enzymes or to enzymes lacking the recognition marker but still capable of hydrolyzing the synthetic MU substrates used in this study. If these enzymes are localized in lysosomes in I-cell 
muscle, this would support the notion that some mechanism other than that involving the phospho-mannose recognition marker is operative in mature muscle. If, however, the activity measured is due to defective enzymes that are not in their proper intracellular locale and therefore presumably not able to degrade intralysosomal substrates, the absence of inclusions in muscle fibers may suggest that these enzymes do not play an important role in mature muscle. Alternatively, mature muscle may have a much reduced rate of endocytosis, resulting in a lesser uptake of "indigestible" material and, consequently, of less intracellular accumulation and the absence of inclusions.

The packaging of lysosomal enzymes is a complex process. The fact that not all lysosomal hydrolases are affected in I-cell disease suggests that different mechanisms may be operative for different enzymes. For example, acid phosphatase, $\beta$-glucosidase, and possibly $\alpha$-glucosidase, may have different recognition markers. It is equally possible that the intracellular localization of the hydrolases into lysosomes may occur via different mechanisms in different tissues (muscle versus connective tissue) and may also differ at various stages in development (myoblasts and developing myotubes versus mature muscle fibers).

\section{REFERENCES AND NOTES}

1. Barka, T., and Anderson, P. J.: Histochemistry. pp. 239-240 (Harper \& Row. New York, 1963).

2. Den Tandt, W. R., Lassila, E., and Phillipart, M.: I-cell disease: markedly increased activity of plasma acid hydrolases. J. Lab. Clin. Med.. 83: 403 (1974).

3. DiDonato, S., Wiesmann, U. N., Rossi, E., and Herschkowitz, N.: Multiple abnormalities of ectoglycosyltransferases in cultured fibroblasts from patients with Mucolipidosis. II. Possible indication for abnormal plasma membrane glycoproteins. Pediatr. Res., 1094 (1977).

4. Hasilik, A., and Neufeld, E. F.: Biosynthesis of lysosomal enzymes in fibroblasts. Phosphorylation of mannose residues. J. Biol. Chem.. 255: 4946 (1980).

5. Hickman, S., and Neufeld, E. F.: A hypothesis for I-cell disease: defective hydrolases that do not enter lysosomes. Biochem. Biophys. Res. Commun., 49: 992 (1972).

6. Hickman, S., Shapiro, L. J., and Neufeld, E. F.: A recognition marker required for uptake of a lysosomal enzyme by cultured fibroblasts. Biochem. Biophys. Res. Commun., 57: 55 (1974).

7. Kaplan, A., Fischer, D., Achord, D., and Sly, W.: Phosphohexosyl recognition is a general characteristic of pinocytosis of lysosomal glycosidases by human fibroblasts. J. Clin. Invest., 60: 1088 (1977).

8. Kula, R. W., Shafiq S. A., and Sher J. H.: In preparation.

9. Leroy, J. G., and Demars, R. 1.: Mutant enzymatic and cytological phenotypes in cultured human fibroblasts. Science (Wash. D.C.). 157: 804 (1967).

10. Leroy, J. G., Ho, M. W., MacBrinn, M. C., Zielke, K., Jacob. J., and O'Brien, J. S.: I-cell disease; biochemical studies. Pediatr. Res., 6: 752 (1972).

11. Leroy, J. G., Spranger, J. W., Feingold, M., Opitz. J. M., and Crocker, A. C.: I- cell disease: a clinical picture. J. Pediatr., 79: 360 (1971)

12. Lightbody, J., Weismann, U. N., Hadorn, B., and Herschkowitz, N.: I-cell disease: multiple lysosomal enzyme defect. Lancet, 1: 451 (1971)

13. Lowry, O. H., Rosebrough, N. J., Farr, A. L., and Randall, R. I.: Protein measurement with the Folin phenol reagent. J. Biol. Chem., 193: 265 (1951).

14. Martin, J. J., Leroy, J. G., Farriaux. J. P., Fontaine, G., Desnick, R. J., and Cabello, A.: I-cell disease (Mucolipidosis II): a report on its pathology. Acta Neuropathol., 33: 285 (1975)

15. Miranda, A. F., Somer, H., and DiMauro, S.: Isozymes as markers of differentiation. In: A. Mauro: Muscle Regeneration. pp. 453-473 Raven Press, New York, 1979).

16. Natowicz, M. R., Chi, M. M., Lowry, O. H., and Sly, W. S.: Enzymatic identification of mannose 6-phosphate on the recognition marker for receptormediated pinocytosis of $\beta$-glucuronidase by human fibroblasts. Proc. Natl. Acad. Sci. U. S. A., 76: 4322 (1979).

17. Neufeld, E. F., Lim, T. W., and Shapiro, L. J.: Inherited disorders of lysosomal metabolism. Ann. Rev. Biochem., 44: 357 (1975).

18. Neufeld. E. F., Sando, G. N., Garvin, A. J., and Rome, L. H.: The transport of lysosomal enzymes. J. Supramol. Struct., 6: 95 (1977).

19. Penn, A. S.. Schotland. D. L., and Lamme, S.: Comparison of anti-muscle antibodies and anti-receptor antibodies in myasthenia gravis. (Submitted for publication).

20. Sando, G. N., and Neufeld, E. F.: Recognition and receptor-mediated uptake of a lysosomal enzyme, $\alpha$-L-iduronidase by cultured human fibroblasts. Cell, 12: $619(1977)$.

21. Sly. W. S., Lagwinska, E., and Schlesinger, S.: Enveloped virus acquires membrane defect when passaged in fibroblasts from I-cell disease patient. Proc. Natl. Acad. Sci. U. S. A.. 73: 2443 (1976).

22. Tondeur, M., Vamos-Hurwitz. E.. Mockel-Pohl, S., Derume, J. P., Cremer, N. and Loeb, H.: Clinical, biochemical and ultrastructural studies in a case of chondrodystrophy presenting the I-cell phenotype in tissue culture. J. Pediatr. 79: 366 (1971).

23. Wenger, D. A., Sattler, M.. Clark, C., and Wharton, C.: I-cell disease: activities of lysosomal enzymes toward natural and synthetic substrates. Life Sci., 19 : 413 (1976).

24. Wiesmann, U. N., and Herschkowitz. N. N.: Studies on the pathogenetic mechanism of I-cell disease in cultured fibroblasts. Pediatr. Res., 8: 865 (1974).

25. Wiesmann. U. N., Lightbody, D.. Vassella, F.. and Herschkowitz. N. N.: Multiple lysosomal enzyme deficiency due to enzyme leakage? N. Engl. J. Med.. 284: 109 (1971).

26. Yaffe, D.: Retention of differentiation potentialities during prolonged cultivation of myogenic cells. Proc. Natl. Acad. Sci. U. S. A., 61: 477 (1968).

27. Dr. Shanske is a Postdoctoral Fellow of the Muscular Dystrophy Association.

28. The authors are grateful to Dr. Halina Den for helpful discussions, Dr. Judy Willner for providing clinical information, and Rhonda Bunin for typing the manuscript.

29. Requests for reprints should be addressed to: Dr. Salvatore DiMauro, Room 4420, College of Physicians and Surgeons, 630 West 168th Street. New York. NY 10032 (USA).

30. This research was supported by Center Grants NS 11766-06 from the National Institute of Neurological and Communicative Disorders and Stroke and from the Muscular Dystrophy Association.

31. Received for publication October 7, 1980.

32. Accepted for publication February II, 1981. 